\title{
ALAT PEMBERSIH ASAP ROKOK OTOMATIS DENGAN MENGGUNAKAN SENSOR MQ2
}

\author{
Gusrio Tendra ${ }^{1}$, Denok Wulandari ${ }^{2}$ \\ AMIK "Tri Dharma" Pekanbaru \\ Jl. Jend Sudirman No. 68 D Pelita Pantai, Pekanbaru, Riau \\ e-mail : gusriotendra@gmail.com ${ }^{1}$, denokwulandari18@gmail.com ${ }^{2}$
}

\begin{abstract}
ABSTRAK
Penelitian ini dilakukan untuk merancang alat dan menganalisa cara kerja alat pendeteksi asap rokok di dalam ruangan serta membantu menghilangkan asap rokok tersebut. Penelitian ini menggunakan metode penelitian eksperimen yang dilakukan dengan pemilihan bahan, perancangan alat pendeteksi asap rokok, dan pengujian analisis output sensor MQ2. Alat pembersih asap rokok otomatis ini dirancang berdasarkan tingkat pencemaran udara yang sangat buruk. Dengan menganalisa tingkat pencemaran udara dan melihat besarnya tingkat pencemaran udara oleh asap rokok yang dapat menyebabkan gangguan pernafasan bahkan kematian di lingkungan masyarakat. Hasil pengujian dan analisis menunjukan bahwa semakin jauh jarak sensor dengan asap maka semakin lama waktu yang dibutuhkan sensor untuk mendeteksi asap dengan tegangan output sensor sebesar $1.45 \mathrm{v}$ maka nilai data DAC 290, tegangan output sensor $1,48 \mathrm{v}$ data DAC 296, tegangan out sensor 1,54 v DAC 308, tegangan out sensor 1,58 v data DAC 316, dan tegangan out sensor 1,61 v nilai data DACnya 322. Nilai output DAC 308 terdapat asap, dan apabila output DACnya 296, maka kondisi ruangan tidak terdapat asap rokok.
\end{abstract}

Kata kunci: ATmega8535, IC ISD2560, Sensor asap MQ2

\begin{abstract}
This research was conducted to manage the tool and analyze the workings of detecting cigarette smoke in the room and help eliminate the cigarette smoke. This study uses an experimental research method which is conducted by selecting materials, designing an immediate detection device, and testing an MQ2 sensor output analysis. This automatic cigarette smoke cleaning tool is designed based on very bad levels of air pollution. By analyzing the level of air pollution and see the level of air pollution by smoke which can cause respiratory problems and even death in the community. The results of testing and analysis show that the faster the remote sensor, the longer the required sensor time increases with the sensor output of 1.45 v, the DAC 290 data value, the sensor output voltage $1.48 v$ DAC 296 data, the output voltage sensor 1, 54 v DAC 308, output voltage sensor 1.58 v DAC 316 data, and output voltage sensor 1.61 v DAC data value 322. DAC 308 output value is needed as soon as possible, and the DAC output 296 can be calculated, so the possibility of smoke is not available. .
\end{abstract}

Keywords: ATMega8535, IC ISD2560, MQ2 Smoke Detectors

\section{PENDAHULUAN}

Terjadinya gangguan pernafasan atau penyakit pada pernafasan dapat disebabkan oleh dampak dari polusi udara. Penyakit yang ditimbulkan dari polusi udara dapat berdampak pada kematian. Rata-rata orang Indonesia dapat kehilangan 1,2 tahun harapan hidup pada tingkat polusi saat ini, menurut Indeks Kualitas Udara Kehidupan (AQLI), karena kualitas udara gagal memenuhi pedoman Organisasi Kesehatan Dunia (WHO) untuk konsentrasi unsur partikulat halus (Greenstrone dan Fan, 2019).

Berdasarkan data Globocan menunjukkan bahwa total kematian akibat paparan polusi udara yang menyebabkan kanker paru-paru di Indonesia menempati urutan pertama penyebab kematian yaitu ialah sebesar $12.6 \%$. 


\section{INFORM TIK}

Jurnal Informatika, Manajemen dan Komputer, Vol. 12 No. 1, MEI 2020

eISSN : 2580-3042

pISSN : 1979-0694

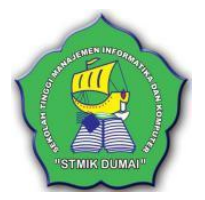

Asap beracun yang ditimbulkan oleh rokok merupakan salah satu bentuk dari penyebab polusi udara. Kandungan racun yang terdapat pada asap rokok dapat menyebabkan gangguang pada pernafasan, tidak hanya bagi orang yang menghirup rokok, tetapi racun dari asap rokok tersebut juga dapat terhirup oleh orang disekitar perokok tersebut terlebih jika perokok tersebut berada pada satu ruangan tertutup yang minim sirkulasi udara (Nurjanah, dkk, 2014).

Oleh sebab itu penelitian ini dilakukan bertujuan untuk membangun sebuah alat yang dapat mengurangi penyebaran racun yang ditimbulkan oleh rokok pada suatu ruangan. Alat ini akan dibangun dengan memanfaatkan Sensor Asap MQ2. Diharapkan dengan menggunakan alat tersebut dapat mengurangi dampak dari penyebaran rancun yang terkandung pada asap rokok.

Sensor Asap MQ2 merupakan sensor yang dapat berfungsi untuk mengamati tingkat kontaminasi udara yang disebakan oleh asap yang memiliki konsentrasi rendah seperti gas $\mathrm{H} 2 \mathrm{~S}$ yang disebabkan dari asap hasil pembakaran material rumah tangga dan perkantoran.

\section{METODOLOGI PENELITIAN}

Metodologi penelitian yang digunakan pada penelitian ini ialah metode pengembangan sistem yang disebut System Development Life Cycle (SDLC). Dimana dalam pengembangan sistem, proses pada metode SDLC digunakan untuk menghubungkan semua langkah yang diperlukan dalam menganalisa, merancang, membangun, mengimplementasi serta memelihara sistem. Gambar 1 dibawah ini merupakan bagan dari SDLC yang digunakan peneliti.

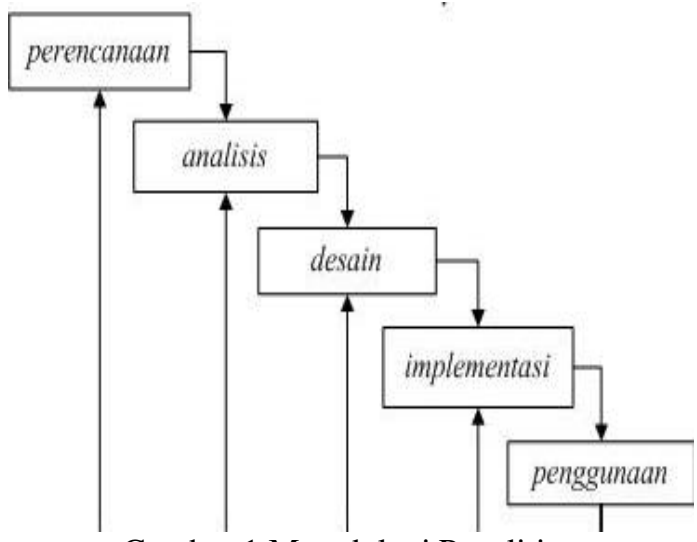

Gambar 1 Metodologi Penelitian

\section{HASIL DAN PEMBAHASAN}


INFORMATIKA

Jurnal Informatika, Manajemen dan Komputer, Vol. 12 No. 1, MEI 2020

elSSN : 2580-3042

pISSN : 1979-0694

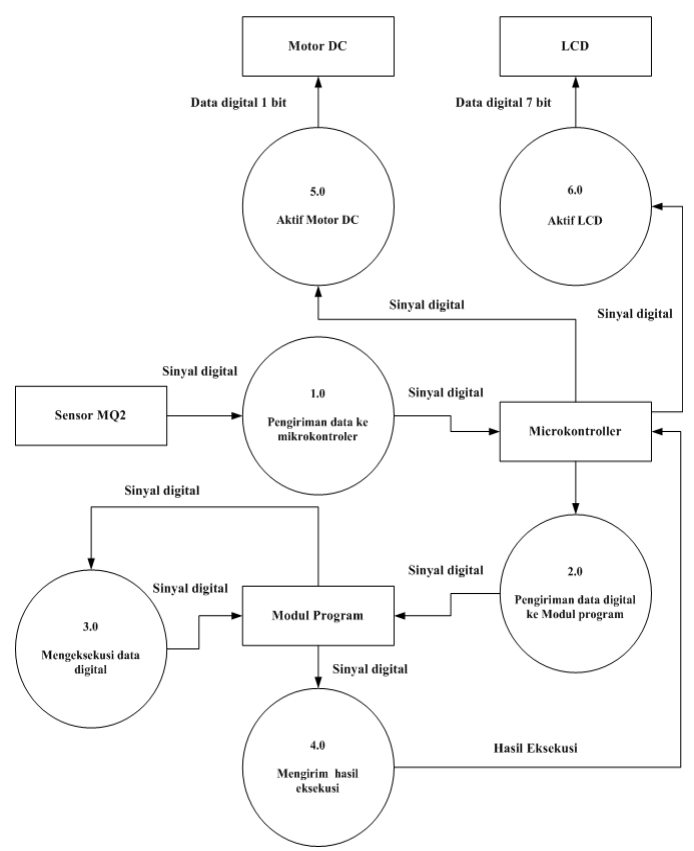

\subsection{PENGUJIAN SISTEM}

Berikut langkah-langkah yang dapat dilakukan dalam pengujian dari sistem pembersih asap rokok otomatis :

a. Hubungkan seluruh rangkaian ke sistem minimum dan power supply. Gambar pemasangan rangkaian dapat dilihat pada gambar 5 seperti dibawah :



Gambar 5 Pemasangan Rangkaian

Gambar 3 Data Flow Diagram

\subsection{FLOWCHART DIAGRAM}

Adapun modul program atau flowchart dalam pembuatan sistem pengamaman pintu adalah sebagai berikut. Program flowchart sistem yang dibuat dilihat pada gambar 4 berikut :

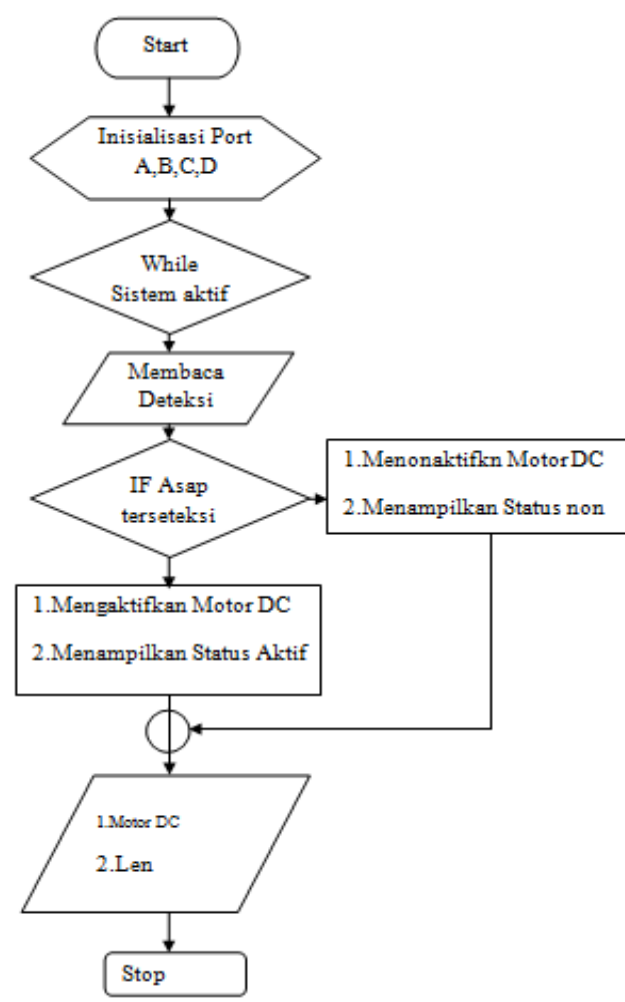

Gambar 4 Data Flow Diagram

b. Pasang kabel power pada power supply ke arus listrik AC terlebih dahulu. Gambar kabel power dapat dilihat pada gambar 6 berikut ini :

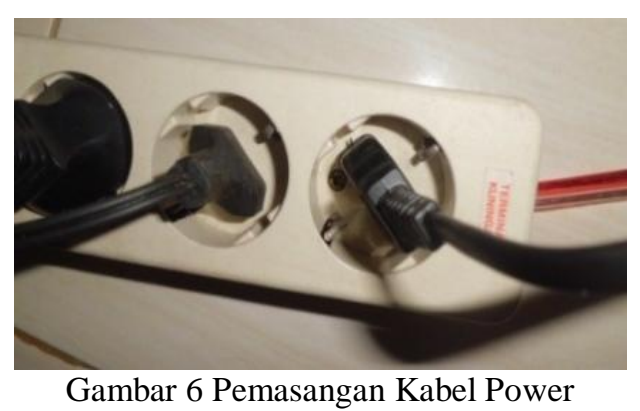

c. Setelah itu pengecekan kondisi LCD telah terpasang dengan sempurna agar proses berjalan degnan baik. Contoh di lihat pada gambar 7 berikut :

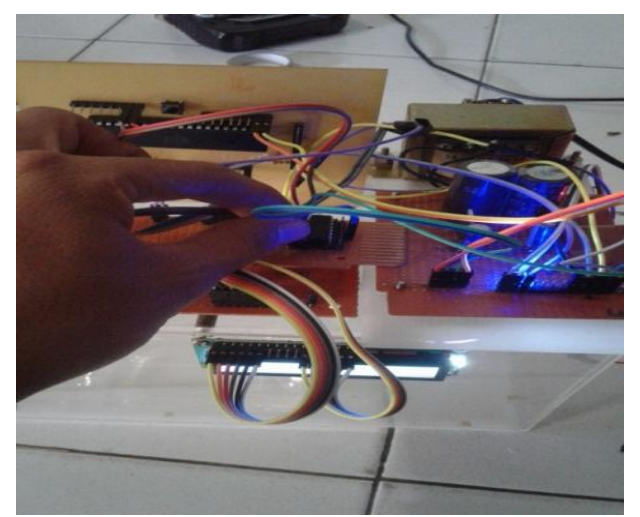

Gambar 7 Pengecekan Kabel LCD 


\section{INFORMATIK}

Jurnal Informatika, Manajemen dan Komputer, Vol. 12 No. 1, MEI 2020

eISSN : 2580-3042

pISSN : 1979-0694

d. Kemudian masuk ketahap pengecekan Sensor Asap (MQ2) apakah sudah terpasang dengan baik. contoh gambar 8 dilihat pada pada gambar sebagai berikut :

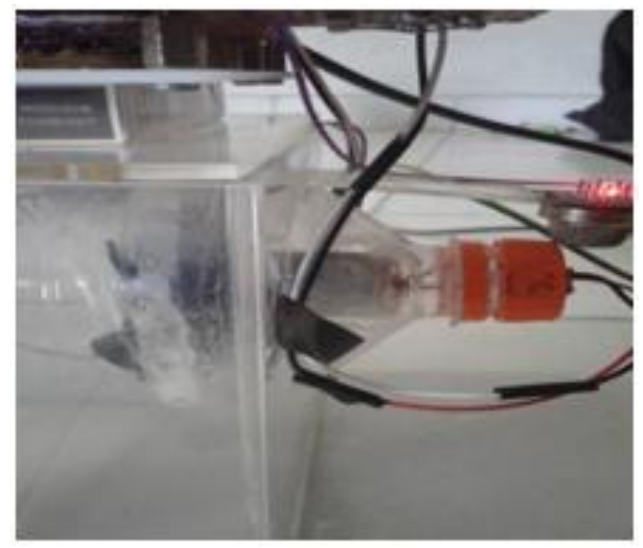

Gambar 8 Pengecekan sensor MQ2

e. Kemudian pengecekan motor DC dapat di lihat pada gambar 9 berikut :

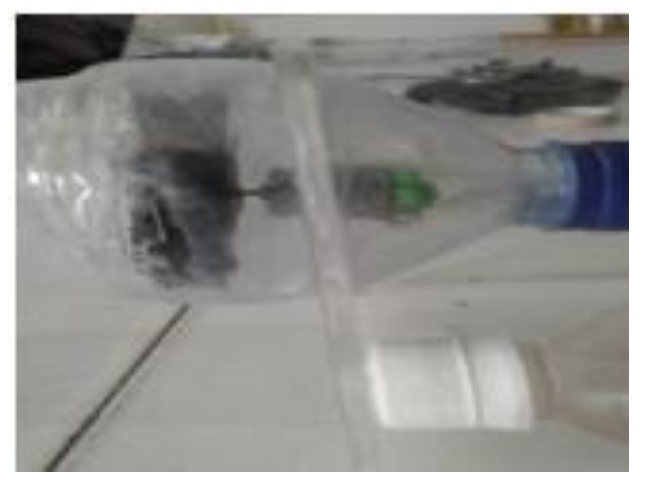

Gambar 9 Pengecekan Motor DC

f. Gambaran sistem pembersih asap rokok otomatis yang telah penulis buat dapat dilihat pada gambar 10 berikut:



Gambar 10 Sistem Pembersih Asap Rokok

\section{KESIMPULAN}

Berikut kesimpulan yang di dapat dari pembahasan sebelumnya:

a. Aplikasi ATmega 8535 pada sistem pembersih asap rokok berbasis bahasa $\mathrm{C}$ merupakan prototype alat yang dapat berguna dalam kehidupan sehari-hari terutama dapat membantu mengurangi asap rokok.

b. Alat yang dirancang ini akan memiliki banyak benefit yang seperti: berkurangnya polusi udara yang tercemar dari asap rokok, dari perokok aktif maupun pasif.

\section{REFERENSI}

Nurjanah, Lily Kresnowati, A. M. (2014). Gangguan Fungsi Paru Dan Kadar Cotinine Pada Urin Karyawan Yang Terpapar Asap Rokok Orang Lain. KESMAS - Jurnal Kesehatan Masyarakat, 10(1), 43-52. https://doi.org/10.15294/kemas.v10i1.3069

Michael Greenstone, Q. F. (2019). Kualitas Udara Indonesia yang Memburuk dan Dampaknya terhadap Harapan Hidup.

Afyenni, R. (2014). Perancangan Data Flow Diagram untuk Sistem Informasi Sekolah (Studi Kasus Pada SMA Pembangunan Laboratorium UNP). Teknoif, 2(1), 35-39.

Gallaleo I Wibowo, A. M. Rumagit, ST., MT, N. J. Tuturoong, ST., M. K. (2014). Perancangan Aplikasi Gudang Pada PT. Pakan Ternak Sejati. E-Journal Teknik Elektro Dan Komputer, 3(4), 11-18. 